\title{
ЦЕННОСТНЫЕ ОРИЕНТАЦИИ И МОТИВАЦИЯ ДОСТИЖЕНИЯ УСПЕХА СТУДЕНТОВ ВУЗОВ
}

\author{
А.С. Милентьева \\ Московский гуманитарный университет
}

Аннотация: Автор ставит и отвечает на актуальные для студентов вопросы: как суметь достичь своих иелей, представляющих стратегическую ијенность личности и какими качествами, нужно обладать для достижения успеха и избегания неудач?

Ключевые слова: мотив, стимул, мотиващия, иченностные ориентащии, достижение успеха

\section{VALUE ORIENTATION AND ACHIEVEMENT MOTIVATION OF SUCCESS OF UNIVERSITY STUDENTS}

\author{
A. S. Melentieva \\ Moscow University for the Humanities
}

\begin{abstract}
The author poses and answers relevant questions for students: how to achieve your goals, which are of strategic value to the individual, and what qualities do you need to have in order to achieve success and avoid failure?
\end{abstract}

Keywords: motive, incentive, motivation, value orientations, achievement of success

Усиление творческой активности человека, стремления к труду, самоопределению и самосовершенствованию - одна из центральных задач, стоящих перед обществом на современном этапе развития. Решение этой сложной задачи особо остро ставит вопрос о необходимости развития мотивационной сферы личности. В связи с этим большую значимость приобретает исследование таких широких форм мотивации, которые, проявляясь в разных сферах деятельности (профессиональной, научной, учебной и т.п.), определяют творческое, инициативное отношение к делу, влияют как на характер, так и на качество выполнения труда. Одним из основных видов такой мотивации выступает мотивация достижения успеха, определяющая стремление человека выполнять любое дело качественно.

Мотивация достижения успеха - это потребность достичь цели, а ценностные ориентации - это сами желаемые, стратегически важные для человека цели. Это ценности, которые отражены в сознании человека и являются для него мировоззренческим ориентиром. Можно сказать, что при отсутствии мотивации достижения успеха человек не сможет реализовать и удовлетворить свои потребности. Когда личность не удовлетворяет свои потребности - она чувствует себя несчастной, что может привезти к психологическим болезням, таким как депрессия.

Наиболее известными теориями мотивации достижения являются: теория 
иерархии потребностей А. Маслоу, теория ERG (потребностей существования роста и связей), разработанная К. Альдерфером, теория приобретенных потребностей Д. Мак-Клелланда, теория двух факторов Ф. Герцберга, теория ожиданий В. Врума, модель Портера-Лаулера (Теория мотивации).

Мотив занимает главное место в теории мотивации достижения. Мотив, это осознанное побуждение удовлетворить свои потребности, т.е. это - толчок и причина, по которой человек начинает что-то делать. Нередко вы можете слышать от знакомых или узнать в этой фразе себя: «Я все понимаю, но я не могу, у меня не получается, нет времени и т.д.»- т.е. есть желание, но нет мотива, или он есть, но не актуализован. Если человек может актуализовать мотив, то ему гораздо легче достичь успеха, ведь в этом случае в ход идет волевая сторона поведения и мотив становится движущей силой, если он осознан. В человеческом подсознании существует множество мотивов, а актуализуется наиболее сильный из них.

Следующим составляющим теории мотивации достижения являются: притязания; уровень удовлетворения потребностей; ожидание. Притязания - это уровень удовлетворения потребностей, стремление получить желаемое.

Это хорошо иллюстрирует знаменитая пирамиду Маслоу. Человек постоянно ощущает какие-то потребности, и если они не удовлетворены, то побуждают человека к действиям. Удовлетворенные же потребности не мотивируют. Когда одна потребность удовлетворяется, то на смену ей приходит другая, еще неудовлетворенная. В пирамиде они расположены в иерархическом порядке, ближайшие к основанию потребности являются первостепенными. Необходимости более высокого уровня начинают действовать только в том случае, если в той или иной степени удовлетворены потребности более низкого уровня (Маслоу, 2006).

Ожидание - событие, которое рассматривается как наиболее вероятное в ситуации неопределённости. То есть у людей могут быть одинаковые притязания, но разные ожидания. Это также влияет на достижение успеха.

Педагогу следует учитывать разный уровень притязаний и ожиданий студента. Например, для студента, который получал удовлетворительные оценки в школе, будет сильным стимулом получение более высокой оценки, например 4 , когда такая же оценка для отличника станет демотивирующим фактором.

Третьим составляющим мотивации является стимул. Стимул - это внешний мощнейший побудительный толчок, заставляющий человека действовать. Стимулирование - это процесс воздействия на человека для повышения его работоспособности. Лучше использовать как материальные, так и нематериальные виды стимулов (Ильин, 2006).

Ценностные ориентации также, как и мотивы являются важнейшими составляющими личности. Ценностные ориентации - это представление человека о ценностях, признание их в качестве важнейших в жизни. У разных людей различные ценности, а значит, они по-разному ценностно ориентированы. Элементами 
ценностных отношений являются условия жизни, деятельность, а также склонности, способности, интересы, потребности человека. В условиях современности, проблема ценностных ориентаций молодого поколения приобретает высокую значимость, т.к. выполняет функции регуляции поведения и построения их целей.

Согласно теории С. Шварц и В. Билски, ценности - это так называемые критерии выбора и оценки поведения и поступков человека. В своей теории авторы выводят основные типы мотивации, которые и определяют направленность действий индивида (Карандашев, 2004).

Мотивация достижения успеха и ценностные ориентации неразрывно связаны. Чтобы подобрать правильные инструменты мотивации, необходимо знать стратегически важные ценности человека.

Оба эти понятия - «ценностные ориентации» и «мотивация достижения успеха» занимают главное место в деятельности педагога, именно ценностные ориентации влияют на качество работы студентов. Данной проблемой занимались такие ученые, как Л.С. Выготский, И.Ф. Исаева, С.Л. Рубинштейн, В.А. Сластенина, Б.Ф. Ломова, Е.Н. Шиянова и другие.

Ценностные ориентации бывают объективными, т.е. обусловленными общечеловеческими потребностями, связанными с особенностями общества в котором существуют, и субъективными - личные особенности мировоззрения человека.

Итак, рассмотрим общие ценности человека:

Здоровье - важнейшая ценность в жизни людей. Под здоровьем понимается не только физическое, но и духовное, и психическое, которое может негативно сказываться на мотивацию достижения успеха, проявляясь социальными кризисами.

Благосостояние также имеет важное значение в обществе, наличие его отражается во внешнем виде и признании в обществе, которые повышают уровень мотивации достижения успеха.

Хорошее образование в современном обществе является залогом успешной жизни, получения высокой должности и высокой зарплаты.

Семья - также одна из основных ценностей человека, несмотря на современные тенденции не заводить семейные отношения и многочисленные разводы. Человек, имеющий семью, знает для чего он должен развиваться и добиваться успеха. Появление и наличие детей повышает уровень мотивации достижения успеха в разы. Для многих людей дети все еще остаются смыслом жизни,--оставить после себя потомство, которое будет продолжать существование рода и после смерти родителя.

Культурные ценности более характерны для творческих людей. Желание оставить после себя культурную ценность - книги, картины или скульптуры заставляют человека творить. 
Духовные ценности, например, любовь, это движущая сила для любого человека, способного к сильным чувствам. Чего только не делают влюбленные ради своей второй половины.

Нравственные ценности, например, свобода или уважение. Любое из этих ценностей очень важно для человека. Каждый хочет быть свободным в своих действиях, стремлениях, желаниях, и сделает все от него зависящее, чтобы стать таковым.

Есть и другие ценности, например, друзья, уверенность в себе, независимость, любимая работа, путешествия и т.д.

Известно, что ценностные ориентации формируются в подростковом и юношеском возрасте, проведено уже множество исследований, которые показывают, что современная молодежь ориентирована на материальное благосостояние, свободу и независимость. К сожалению, наименьшее значение для нынешних молодых имеют культурные ценности. Также большинство студентов ориентированы на избегание неудач, нежели на достижение успеха. В будущем такое поведение не приведет к развитию, а заставит человека стоять на месте, страх дальше учиться, страх поменять работу, даже страх завести семью. Человек способен на невозможное, если действительно этого желает, если ставит перед собой цель и считает, что ее достижение - первостепенная ценность личности (Ансимова, Мишучкова, 2016).

Значительную роль в развитии мотивации достижения успеха играют особенности личности и уровень развития ее способностей: высокая способность к обучению; абстрактность мышления; эмоциональная устойчивость; нормативность поведения и суждений; скорее консервативность и следование правилам, уважение принципов, чем критичность и свободомыслие; скорее практичность, чем склонность к применению своего воображения; выраженность волевых качеств.

Ю.Н. Рыжая провела исследования, из которого можно определить, что ценностные ориентации действительно влияют на представление человека об условиях достижения успеха (Рыжая, 2008).

По данным опроса современная молодежь высоко оценивает стремления, целеустремленность и активность, в то время, как предыдущие поколения ставку делали на ум и компетентность. Трудолюбие и самосовершенствование заметно сдали позиции, а значимость интеллектуальных способностей осталась прежней. В наше время наличие высокого уровня компетенции и интеллекта не дает гарантий получения работы и достойной должности, успеха в будущем, таким образом образование становится не так значимо. Студенты наблюдают за ситуацией в стране, и ощущают несправедливость и ненужность, там самым приходят к выводу, что не заслуги и достоинства являются залогом успеха, а совсем другое, скорее материальное благо. В сравнении с предыдущими поколениями ценность 
«влиятельных родственников и друзей», «блата» выросло аж в два раза. Это говорит о росте популярности безнравственного успеха.

Из исследований А.В. Соколова можно сделать вывод, что важной ценностью для молодежи является эгоизм, с помощью которого можно добиться желанного успеха. Такая тенденция приводит так же к снижению ценности семьи и дружбы, что в конечном итоге приведет к отчуждению от общества (Соколов, 2005).

Исходя из диссертационного исследования Л.М. Хабаевой у студентов юридического факультета также обнаружено недостаточное осознание необходимости профессионального образования и ценностно-смыслового восприятия будущей профессии, и это проблема не только испытуемых, но большинства студентов российских вузов (Хабаева, 2002).

У молодого поколения снижается уровень интеллектуального развития, желание к получению высшего образования. Сейчас перед системой высшего образования необходимо поставить следующую задачу: развивать и корректировать личность студента, а также оказывать психологопрофессиональное консультирование по вопросам профессиональной ориентации, развития профессионально важных качеств. Значимым механизмом влияния ценностных ориентаций на развитие мотивации достижения успехов студентов является ценностно-смысловое отражение деятельности как самого студента, общества, в котором он существует, так и преподавателя, выявляющее базовые потребности развития студентов в получении качественной и полной информации, в объективности оценки знаний, в организации индивидуального подхода профессионального обучения.

\section{СПИСОК ЛИТЕРАТУРЫ}

Ансимова Н.П., Мишучкова Е.Ю. (2016) Ценностные ориентации и мотивация студентов педагогического вуза / Ярославский педагогический вестник. №1// URL: https://cyberleninka.ru/article/v/tsennostnye-orientatsii-i-motivatsiya-dostizheniya-studentov-pedagogicheskogo-vuza.

Безрукова А.Н., Тимофеева Т.С., Коваленко С.Н. (2016) Взаимосвязь ценностных ориентаций с уровнем притязаний и мотивацией достижения успеха / Инновации в науке: сб. ст. по матер. LXIV Междунар. науч.-практ. конф. № 12(61). Часть II. - Новосибирск: СибАК, 2016. - С. 17-21. //URL: https://sibac.info/conf/innovation/ 1xiv/66789 (дата обращения: 20.12.2020).

Ильин Е.П. (2006) Мотивация и мотивы. // СПб.: Питер. С. 543.

Карандашев В.Н. (2004) Методика Шварца для изучения ценностей личности: концепция и методическое руководство. СПб.: Речь. С. 275.

Маслоу А. (2006) Мотивация и личность. СПб.: Питер. С. 352.

Рыжая Ю.Н. (2008) Факторы жизненного успеха в представлениях современного студента // Вестник КГПУ им. В.П. Астафьева. № 2. С. 50. 
Соколов А.В. (2005) Интеллектуально-нравственная дифференциация современного студенчества. // Социсс, № 9.

Теории мотивации: [Электронный ресурс]. URL: http://www.grandars.ru/college/ psihologiya/osnovnye-teorii-motivacii.html (дата обращения: 20.12.2020).

Хабаева Л.М. (2002) Влияние ценностных ориентаций на развитие профессиональной мотивации студентов вуза: дис. ... канд. псих. наук. М., С. 158.

Милентьева Алена Сергеевна - обучающийся 3 курса образовательной программы магистратуры по направлению подготовки 44.04.02 Психолого-педагогическое образование Московского гуманитарного университета. Научный руководитель: В.Г. Тылец, доктор психологических наук, профессор кафедры фонетики и грамматики французского языка, Московский государственный лингвистический университет. Адрес: 111395, Россия, г. Москва, ул. Юности, д. 5. Тел.: +7 (499) 37474-59. Эл. адрес: pp.mosgu@mail.ru

Milentyeva Alyona Sergeevna - 3-year student of the master's degree program in the field of training 44.04.02 Psychological and pedagogical education, Department of Pedagogy and Psychology of the Higher School of the Moscow humanitarian University. Scientific Adviser - V.G. Tylets, doctor of psychological sciences, professor, professor of the department of phonetics and grammar of the French language of the Moscow Linguistic University. Address: 5 Yunosti str., Moscow, 111395, Russia. Phone: +7 (499) 374-74-59. Email: pp.mosgu@mail.ru

\section{Для цитирования:}

Милентьева А.С. Ценностные ориентации и мотивации достижения успеха студентов вузов // Научные труды Московского гуманитарного университета. 2020. №6. C. 56-61. DOI: https://www.doi.org/10.17805/trudy.2020.6.10 